\title{
Pentingnya Diagnosa Keperawatan Bagi Perawat Untuk Menghasilkan Intervensi Keperawatan di Rumah Sakit
}

\author{
Christin Butar Butar
}

christinbutarbutar19@gmail.com

\section{LATAR BELAKANG}

Diagnosa keperawatan sangatlah penting dalam proses keperawatan dan merupakan suatu pernyataan yang singkat, tegas, dan jelas mengenai respon klien terhadap masalah kesehatan atau penyakit yang dialami klien. Diagnosa keperawatan bisa ditentukan dari hasil pengkajian keperawatan yaitu pada analisa data yaitu di bagian etiologi yang bisa menghasilkan diagnose keperawatan.

Diagnosa keperawatan merupakan fase kedua dari proses keperawatan. Pada fase ini perawat mengimplementasikan cara berpikir kritis untuk menghasilkan diagnose keperawatan yang akurat. Diagnosa keperawatan ini didapatkan dari hasil analisis data pada tahap pengkajian keperawatan melalui pengumpulan data baik itu dari data objektif maupun subjektif. Diagnosa keperawatan juga merupakan hal yang penting dalam proses keperawatan, semua aktivitas sebelum fase ini ditujukan untuk menentukan diagnosa keperawatan. Pentingnya seorang perawat untuk menentukan diagnosa keperawatan karena dengan menentukan diagnosa keperawatan perawat bisa memutuskan tindakan apa yang akan dilakukan dan asuhan keperawatan yang bagaimana yang akan diberikan kepada klien. Dengan begitu perawat tidak akan membuat klien merasa tidak aman dan nyaman dengan asuhan keperawatan yang diberikan perawat. Dari diagnosa ini juga bisa menentukan intervensi keperawatan yang nantinya menghasilkan implementasi proses keperawatan.

Kata kunci : Diagnosa Keperawatan, Rumah Sakit 


\section{METODE}

Jurnal ini menggunakan metode tersearch dan analisis dari berbagai sumber seperti buku teks, buku referensi jurnal, ebook, dan juga membandingkan beberapa jurnal yang berhubungan dengan diagnosa keperawatan. Dari analisi berbagai sumber digunakan Untuk mengetahui hal-hal yang berkaitan dengan diagnosa keperawatan. Saya membaca dari berbagai referensi berupa buku dan jurnal..

\section{HASIL}

Diagnosa keperawatan merupakan suatu kesimpulan yang dihasilkan dari analisa data, diagnosa keperawatan adalah penilaian klinik mengenai respon individu keluarga, atau komunitas terhadap masalah kesehatan atau proses kehidupan yang aktual atau potensial, diagnosa keperawatan memberikan dasar untuk pemilihan intervensi keperawatan untuk mencapai hasil yang merupakan tanggung jawab perawat. Didapatkan komponen dari diagnosa keperawatan yaitu problem, etiologi, sign and symptom. Komponen keperawatan ini bisa dimanfaatkan untuk lebih mudah dalam menentukan diagnosa keperawatan. Kemudian juga ada tipe-tipe dari diagnosis keperawatan yakni ada diagnosis keperawatan aktual, risiko, sejahtera, diagnosis keperawatan kemungkinan.dan diagnose keperawatan sindroma

Dalam literature review tersebut juga memperoleh hasil bahwa perawat harus mampu meberikan perencanaan yang tepat, efisian dan efektif. kefektifan perawat dalam menentukan diagnosa keperawatan dapat meningkatkan kinerja yang akan dilakukan dan juga kesejahteraan terhadap pasien. Penentuan diagnosa yang tepat dapat mengahsilkan tindakan kesehatan yang tepat juga.

Pentingnya menentukan diagnosa keperawatan bagi klien maka perawat harus dapat menguwasai mengenai diagnosa keperawatan karena dengan diagnosa keperawatanlah yang dapat menghasilkan intervensi yang benar, maka perawat harus benar menguasai diagnosa keperawatan agar dapat menentukan intervensi keperawatan yang tepat. Perawat perlu melakukan diagnosa yang baik dan aktual,sebelum membuat diagnosa pada saat melakukan pengkajian harus dilakukan dengan baik dan benar sehingga pada saat melakukan pengkajian dapat dilakukan dengan detil untuk membuat perawat membuat diagnosa menjadi lebih aktual dan benar. 


\section{PEMBAHASAN}

Defenisi diagnosa keperawatan menurut NANDA ialah dari istilah penegakan diagnosis menunjukkan proses penalaran, sedangkan istilah diagnosis adalah pernyataan atau kesimpulan fenomena. Nama diagnosis yang baku menurut NANDA disebut judul diagnosis, dan pernyataan masalah klien, yang terdiri dari judul diagnosis plus etiologi (hubungan kausal antara masalah dan faktor yang berhubungan atau faktor risiko) itulah yang disebut dengan diagnosis keperawatan. (Kozier, dkk, 2010). Diagnose keperawatan juga diartikan sebagai suatu kesimpulan yang dihasilkan dari analisa data, diagnosa keperawatan adalah penilaian klinik mengenai respon individu keluarga, atau komunitas terhadap masalah kesehatan atau proses kehidupan yang aktual atau potensial, diagnosa keperawatan memberikan dasar untuk pemilihan intervensi keperawatan untuk mencapai hasil yang merupakan tanggung jawab perawat. (Carpenito, 2009)

Diagnosa keperawatan sangatlah penting dalam proses keperawatan. Diagnosa keperawatan merupakan suatu pernyataan yang singkat, tegas, dan jelas mengenai respon klien terhadap masalah kesehatan atau penyakit yang dialami klien. Diagnosa keperawatan bisa ditentukan dari hasil pengkajian keperawatan yaitu pada analisa data yaitu di bagian etiologi yang bisa menghasilkan diagnose keperawatan.

Pentingnya seorang perawat untuk menentukan diagnosa keperawatan karena dengan menentukan diagnosa keperawatan perawat bisa memutuskan tindakan apa yang akan dilakukan dan asuhan keperawatan yang bagaimana yang akan diberikan kepada klien. Dengan begitu perawat tidak akan membuat klien merasa tidak aman dan nyaman dengan asuhan keperawatan yang diberikan perawat. Dari diagnosa ini juga bisa menentukan intervensi keperawatan yang nantinya menghasilkan implementasi proses keperawatan.

\section{Komponen Diagnosa Keperawatan}

a. Problem (Masalah)

Merupakan gambaran keadaan klien dimana tindakan keperawatan dapat diberikan. Masalah adalah kesenjangan atau penyimpangan dari keadaan normal yang seharusnya tidak terjadi. Tujuan : menjelaskan status kesehatan klien atau masalah kesehatan klien secara jelas dan sesingkat mungkin. Diagnosis keperawatan disusun dengan menggunakan standart yang telah disepakati (NANDA, Doengoes, Carpenito, Gordon), supaya : 
a. Perawat dapat berkomunikasi dengan istilah yang dimengerti secara umum

b. Memfasilitasi dan mengakses diagnosa keperawatan

c. Sebagai metode untuk mengidentifikasi perbedaan masalah keperawatan dengan masalah medis

d. Meningkatkan kerjasama perawat dalam mendefinisikan diagnosis dari data pengkajian dan intervensi keperawatan, sehingga dapat meningkatkan mutu asuhan keperawatan

\section{b. Etiologi (Penyebab)}

Keadaan ini menunjukkan penyebab keadaan atau masalah kesehatan yang memberikan arah terhadap terapi keperawatan. Penyebabnya meliputi : perilaku, lingkungan, interaksi antara perilaku dan lingkungan.

Unsur-unsur dalam identifikasi etiologi:

a. Patofisiologi penyakit : adalah semua proses penyakit, akut atau kronis yang dapat menyebabkan / mendukung masalah.

b. Situasional : personal dan lingkungan (kurang pengetahuan, isolasi sosial)

c. Medikasi (berhubungan dengan program pengobatan atau perawatan): keterbatasan institusi atau rumah sakit, sehingga tidak mampu memberikan perawatan.

d. Maturasional :

- Adolesent : ketergantungan dalam kelompok

- Young Adult : menikah, hamil, menjadi orang tua

- Dewasa : tekanan karier, tanda-tanda pubertas

c. Sign dan symptom (Tanda dan Gejala)

Adalah ciri, tanda atau gejala, yang merupakan informasi yang diperlukan untuk merumuskan diagnosis keperawatan. Komponen sign dan symptom menjelaskan mengenai data subyektif dan obyektif yang ditemukan sebagai komponen pendukung terhadap diagnosa keperawatan. Sign and symptom (tanda dan gejala) yang merupakan ciri, tanda atau gejala yang merupakan informasi yang diperlukan untuk merumuskan diagnosa keperawatan. (Repository Unimus) Komponen ini sangat penting untuk membantu menentukan diagnosa keperawatan. 


\section{Menurut NANDA Komponen Diagnosa Keperawatan Sebagai Berikut:}

a. Label Diagnosis yang merupakan nama diagnosa keperawatan yang disetujui oleh NANDA International, menggambarkan inti dari respon klien terhadap kondisi kesehatan dalam kata-kata yang sedikit mungkin dan melibatkan pengunaan kata penjelas atau descriptor sebagai contoh, diagnosis gangguan mobilitas fisik disini yang termasuk descriptornya adalah gangguan untuk menjelaskan keaslian ataupun perubahan mobilitas yang mengambarkan dengan baik respon klien.

b. Faktor Terkait adalah kondisi atau etiologi yang ditemukan dari data pemeriksaan klien berhubungan dengan respons potensial atau aktual klien terhadap masalah kesehatan dengan menggunakan intervensi keperawatan.

c. Definisi mengambarkan karakteristik identitas respons manusia, sebagai contoh, definisi label diagnosa keperawatan ketidakseimbangan nutrisi: kurang dari kebutuhan tubuh adalah ketidakmampuan memakan makanan.

d. Faktor Resiko adalah elemen lingkungan, fisiologis, psikologis, genetic, atau kimia yang meningkatkan kerentantan individu, keluarga, atau komunitas terhadap kejadian yang tidak sehat (NANDA Internasional,2007). Faktor resiko merupakan petunjuk yang menunjukan diagnosa keperawatan risiko dapat ditegakkan pada kondisi klien, factor risiko membantu dalam memilih diagnosa risiko yang benar sama halnya dengan karakteristik definisi dalam hal diagnosa keperawatan aktual.

\section{Proses Perumusan Diagnosa Keperawatan}

1. Klasifikasi \& Analisis Data

Pengelompokkan data adalah mengelompokkan data-data klien atau keadaan tertentu dimana klien mengalami permasalahan kesehatan atau keperawatan berdasarkan kriteria permasalahannya. Pengelmpkkan data dapat disusun berdasarkan pola respon manusia (taksonomi NANDA) dan/atau pola fungsi kesehatan (Gordon, 1982)

\section{Mengindentifikasi masalah klien}

Masalah klien merupakan keadaan atau situasi dimana klien perlu bantuan untuk mempertahankan atau meningkatkan status kesehatannya, atau meninggal dengan damai, yang dapat dilakukan oleh perawat sesuai dengan kemampuan dan wewenang yang dimilikinya Identifikasi masalah klien dibagi menjadi : pasien tidak bermasalah, pasien yang kemungkinan mempunyai masalah, pasien yang mempunyai masalah potensial sehingga kemungkinan besar mempunyai masalah dan pasien yang mempunyai masalah aktual. 
3. Memvalidasi diagnosis keperawatan

Adalah menghubungkan dengan klasifikasi gejala dan tanda-tanda yang kemudian merujuk kepada kelengkapan dan ketepatan data. Untuk kelengkapan dan ketepatan data, kerja sama dengan klien sangat penting untuk saling percaya, sehingga mendapatkan data yang tepat.

Pada tahap ini, perawat memvalidasi data yang ada secara akurat, yang dilakukan bersama klien/keluarga dan/atau masyarakat. Validasi tersebut dilaksanakan dengan mengajukan pertanyaan atau pernyataan yang reflektif kepada klien/keluarga tentang kejelasan interpretasi data. Begitu diagnosis keperawatan disusun, maka harus dilakukan validasi.

4. Menyusun diagnosis keperawatan sesuai dengan prioritasnya Setelah perawat mengelompokkan, mengidentifikasi, dan memvalidasi data-data yang signifikan, maka tugas perawat pada tahap ini adalah merumuskan suatu diagnosis keperawatan. Diagnosa keperawatan dapat bersifat aktual, resiko, sindrom, kemungkinan dan wellness.

\section{Klasifikasi Diagnosa Keperawatan}

a. Diagnosa keperawatan aktual (Actual Nursing Diagnoses)

Diagnosa keperawatan aktual menyajikan keadaan yang secara klinis telah divalidasi melalui batasan karakteristik mayor yang dapat diidentifikasi. Tipe dari diagnosa keperawatan ini mempunyai empat komponen yaitu label, definisi, batasan karakteristik, dan faktor-faktor yang berhubungan (Craven \& Hirnle, 2000; Carpenito, 1997).

b. Diagnosa keperawatan risiko dan risiko tinggi (Risk and High-Risk Nursing Diagnoses) Keputusan klinis bahwa individu, keluarga dan masyarakat sangat rentan untuk mengalami masalah bila tidak diantisipasi oleh tenaga keperawatan, dibanding yang lain pada situasi yang sama atau hampir sama (Craven \& Hirnle, 2000; Carpenito, 1997).

c. Diagnosa keperawatan kemungkinan (Possible Nursing Diagnoses)

Pernyataan tentang masalah-masalah yang diduga masih memerlukan data tambahan. Namun banyak perawat-perawat telah diperkenalkan untuk menghindari sesuatu yang bersifat sementara dan NANDA tidak mengeluarkan diagnosa keperawatan untuk jenis ini (Craven \& Hirnle, 2000; Carpenito, 1997). 
d. Diagnosa keperawatan sejahtera (Wellness Nursing Diagnoses)

Ketentuan klinis mengenai individu, keluarga dan masyarakat dalam transisi dari tingkat kesehatan khusus ketingkat kesehatan yang lebih baik. Pernyataan diagnostik untuk diagnosa keperawatan sejahtera merupakan bagian dari pernyataan yang berisikan hanya sebuah label. Label ini dimulai dengan "Potensial terhadap peningkatan", diikuti tingkat sejahtera yang lebih tinggi yang dikehendaki oleh individu atau keluarga, misal "Potensial terhadap peningkatan proses keluarga" (Craven \& Hirnle, 2000; Carpenito, 1997). Diagnosa keperawatan sejahtera menggambarkan respon manusia terhadap tingkat kesejahteraan dalam individu, keluarga, atau komunitas yang memiliki kesiapan untuk peningkatan (NANDA International, 2007). Ini merupakan penilaian klinis tentang individu, keluarga, atau komunitas dalam transisi dari tingkat kesejahteraan tertentu ke tingkat kesejahteraan yang lebih tinggi. Perawat memilih tipe diagnosis ini ketika klien berharap atau telah mencapai tingkat kesehatan yang optimal. Sebagai contoh, potensial peningkatan adaptasi yang terkait dengan keberhasilan pengobatan kanker adalah diagnosis kesejahteraan, dan perawat beserta keluarga bekerjasama untuk beradaptasi dengan stresor yang berhubungan dengan kelangsungan hidup penderita kanker. Dalam pelaksanaanya, perawat menggabungkan kekuatan klien dan sumber daya yang ada ke dalam rencana perawatan, dengan tujuan untuk meningkatkan tingkat adaptasi.

e. Diagnosa keperawatan sindroma (Syndrome Nursing Diagnoses)

Terdiri dari sekelompok diagnosa keperawatan aktual atau risiko tinggi yang diduga akan tampak karena suatu kejadian atau situasi tertentu. NANDA telah menyetujui dua diagnosa keperawatan sindrom yaitu "Sindrom trauma perkosaan" dan "Risiko terhadap sindrom disuse" (Carpenito,1997). 


\section{PENUTUP}

\section{Kesimpulan}

Diagnosa keperawatan adalah keputusan klinis mengenai respon individu, keluarga, atau masyarakat yang diperoleh melalui proses pengumpulan data terhadap masalah kesehatan yang aktual maupun potensial guna menjaga status kesehatan. Dalam merumuskan diagnosa komponen yang harus diperhatikan adalah problem, etiologi, dan sign atau symptom

Proses yang terdapat dalam merumuskan diagnosa adalah sebagai berikut:

- Klasifikasi \& Analisis Data

- Mengindentifikasi masalah klien

- Memvalidasi diagnosis keperawatan

- Menyusun diagnosis keperawatan sesuai dengan prioritasnya.

\section{Saran}

Diharapkan kepada semua perawat untuk dapat menentukan diagnosa keperawatan dengan benar agar intervensi yang diberikan kepada pasien tepat dan asuhan keperawatan berjalan dengan lancar. 


\section{DAFTAR PUSTAKA}

Arif Puji A, Aggorowati. M. Roffi. (2020(. Efektifitas Pedoman Pendokumentasian Diagnosa dan Intervensi Keperawatan Berbasis Android Terhadap Peningkatan Mutu Dokumentasi Keperawatan di Ruang Rawat Inap. Jurnal Keperawatan dan Kesehatan Masyarakat, Vol 9(1), 83-91

Carpenito-Moyet,Lynda Juall.2012. Buku Saku Diagnosis Keperawatan Edisi 13.Jakarta:EGC.

Candra Dewi R, Sri Mulyani. (2020). Pengambilan Keputusan Klinis Perawat. Jurnal Ilmiah Kesehatan

Effendi, Ferry.2009. Keperawatan Kesehatan Komunitas: Teori dan Praktik dalam Keperawatan. Jakarta:Salemba Medika.

Elon Kusnandi. (2017). Analisis Kelengkapan Dokumentasi Keperawatan di Ruang Rawat Inap. Jurnal Bidang Ilmu Kesehatan, Vol 9(1)

Herdman,T.Heather.2012.NANDA International,Diagnosis Keperawatan: Definisi dan Klasifikasi 2012-2014.Jakarta: EGC

Inggriane Puspita D, Nurrohmah, Fikri Rizki F. (2020). Analisis Pengetahuan Perawat Dalam Menentukan Diagnosis Asuhan Keperawatan Spiritual Islami di Rumah Sakit Syariah. Jurnal Ilmiah Keperawatan Indonesia, Vol 4(1)

Made Ermayani, Aprilia, Nuryanti. (2017). Pengembangan Format Dokumentasi Asuhan Keperawatan Berbasis Standardized Nursing Language (SNL) NANDA-1, NOC, NIC di Ruang Rawat Inap. Mahakam Nursing Journal Vol 2(2), 50-61

Simamora, R. H., Bukit, E., Purba, J. M., \& Siahaan, J. (2017). Penguatan kinerja perawat dalam pemberian asuhan keperawatan melalui pelatihan ronde keperawatan di rumah sakit royal prima medan. Jurnal pengabdian kepada masyarakat, 23(2), 300-304. 
Simamora, R. H. (2019). Socialization of Information Technology Utilization and Knowledge of Information System Effectiveness at Hospital Nurses in Medan, North Sumatra. Editorial Preface From the Desk of Managing Editor..., 10(9).

Potter\&Perry.2009.Fundamental of Nursing, $7^{\text {th }}$ Edition.Jakarta:Salemba Medika.

Supratti, Ashriady. (2016). Pendokumentasian Standar Asuhan Keperawatan di Rumah Sakit Umum Daerah Mamuju Indonesia. Jurnal Kesehatan Manarang Vol 2(1) 